\title{
Geology and Geochemistry of Recent Sediments from the Mediterranean Sea: Sediment Texture of Northeastern Mediterranean Basin
}

\author{
Semal Yemenicioglu ${ }^{*}$, Sakir Cagan Tunc ${ }^{2}$ \\ ${ }^{1}$ Institute of Marine Sciences, Middle East Technical University (METU), Mersin, Turkey \\ ${ }^{2}$ Geomarine Kara ve Deniz Araştırmaları, Mersin, Turkey \\ Email: *semal@ims.metu.edu.tr, cagantunc@hotmail.com
}

Received July 31, 2013; revised August 29, 2013; accepted September 6, 2013

Copyright (C) 2013 Semal Yemenicioglu, Sakir Cagan Tunc. This is an open access article distributed under the Creative Commons Attribution License, which permits unrestricted use, distribution, and reproduction in any medium, provided the original work is properly cited.

\begin{abstract}
Surface sediment samples collected from the north-eastern Mediterranean were analysed for their geochemical and sedimentological properties. The sediment texture of the studied area represents a wide variety of sediment types (extending from sandy gravel to mud) and is characterized by relatively high mud content with varying silt and clay fractions. Due to the rich presence of biogenic materials, several coarse-grained sediment patches displaying high $\mathrm{CaCO}_{3}$ content occur. The organic carbon content of the sediments mainly reflects the standard Mediterranean production of organic matter. There are some exceptional areas in coastal zones which result from pollution by perennial river discharge.
\end{abstract}

Keywords: Geochemistry; Coastal Sediment; Grain Size; Carbonate; Organic Carbon; North-Eastern Mediterranean

\section{Introduction}

The study area is located in the north-eastern Mediterranean (southern coast of Turkey). This area covers approximately $7600 \mathrm{~km}^{2}$ and comprises two main submarine sedimentation centres (Mersin Bay and Iskenderun Bay, Figure 1). From west to east, the adjacent coastline can be divided into four regions: the Goksu River Delta; the Erdemli-Mersin coastal plain; delta plain of the Adana Basin; and the Gulf of Iskenderun. The geological characteristics of the research area are summarized in Figure 2.

The present study aims to assess temporal changes in the geochemical composition and physical properties of surface sediments at a specific location through comparison of present results with the findings of previous works done locally in the region [1-8].

\section{Materials and Methods}

Forty-eight surface sediment samples were collected at water depths varying from $12 \mathrm{~m}$ to $330 \mathrm{~m}$ (Figure 1). Samples were obtained by means of the Dietz LaFonde grab sampler which collects the upper $10 \mathrm{~cm}$ layer. The top $2 \mathrm{~cm}$ portion of the samples (recent sediments) were removed, placed into pre-cleaned plastic bags and kept

${ }^{*}$ Corresponding author. frozen until analysis. The grain size compositions and various geochemical properties such as carbonate, organic carbon were determined.

Grain Size Analyses: Grain size analyses were performed by standard sieve and pipette analysis techniques [9]. The grain size distribution of each sediment sample was grouped into four categories as follows; gravel $(>2$ $\mathrm{mm})$, sand $(2-0.063 \mathrm{~mm})$, silt $(0.063-0.0039 \mathrm{~mm})$ and clay $(<0.0039 \mathrm{~mm}$ in diameter $)$.

Geochemical Analyses: In order to determine the geochemical properties of the surface sediments, approximately $100 \mathrm{~g}$ of subsample was freeze-dried and powdered using an agate mortar and pestle. Total carbonate contents of the sediment samples were calculated by a modified gravimetric-volumetric method described in [10]. The analytical method for the quantitative determination of organic carbon is based on the complete and instantaneous oxidation of the sample by "high temperature flash combustion" and measured by using a Thermo Finnigan Flash EA 1112 Series elemental analyser.

\section{Results and Discussion}

\subsection{Grain Size Distribution}

The surface sediments of the studied area show various 


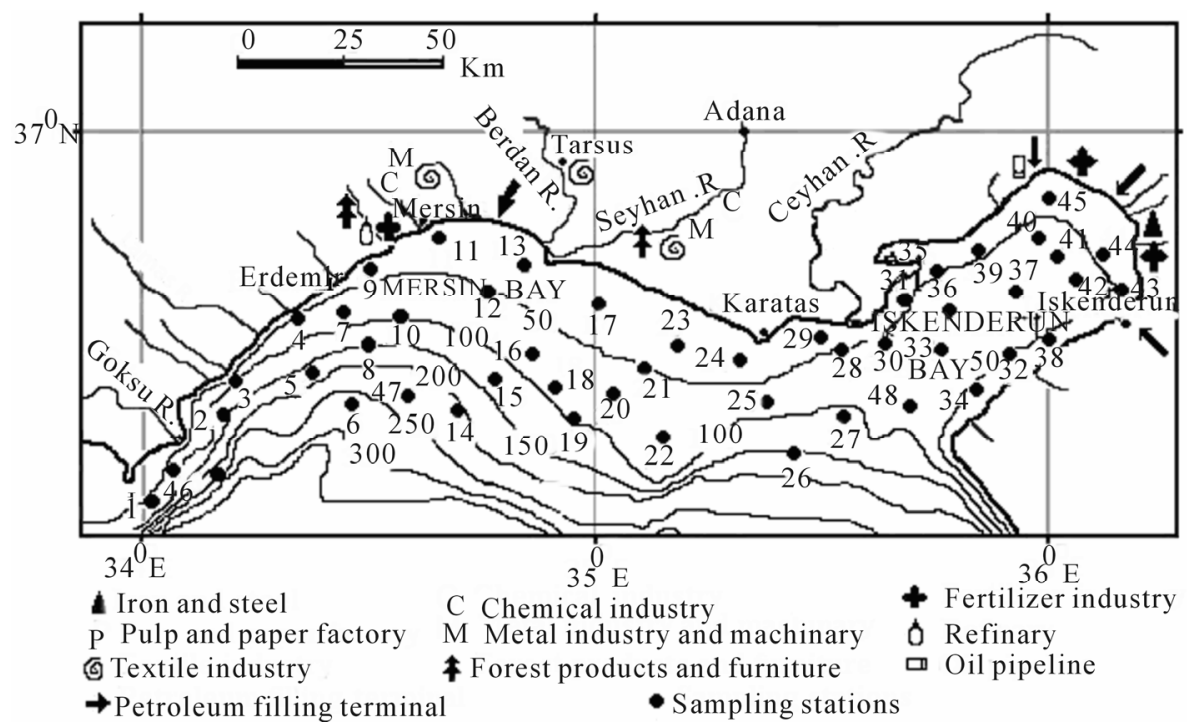

Figure 1. Sediment sampling locations.

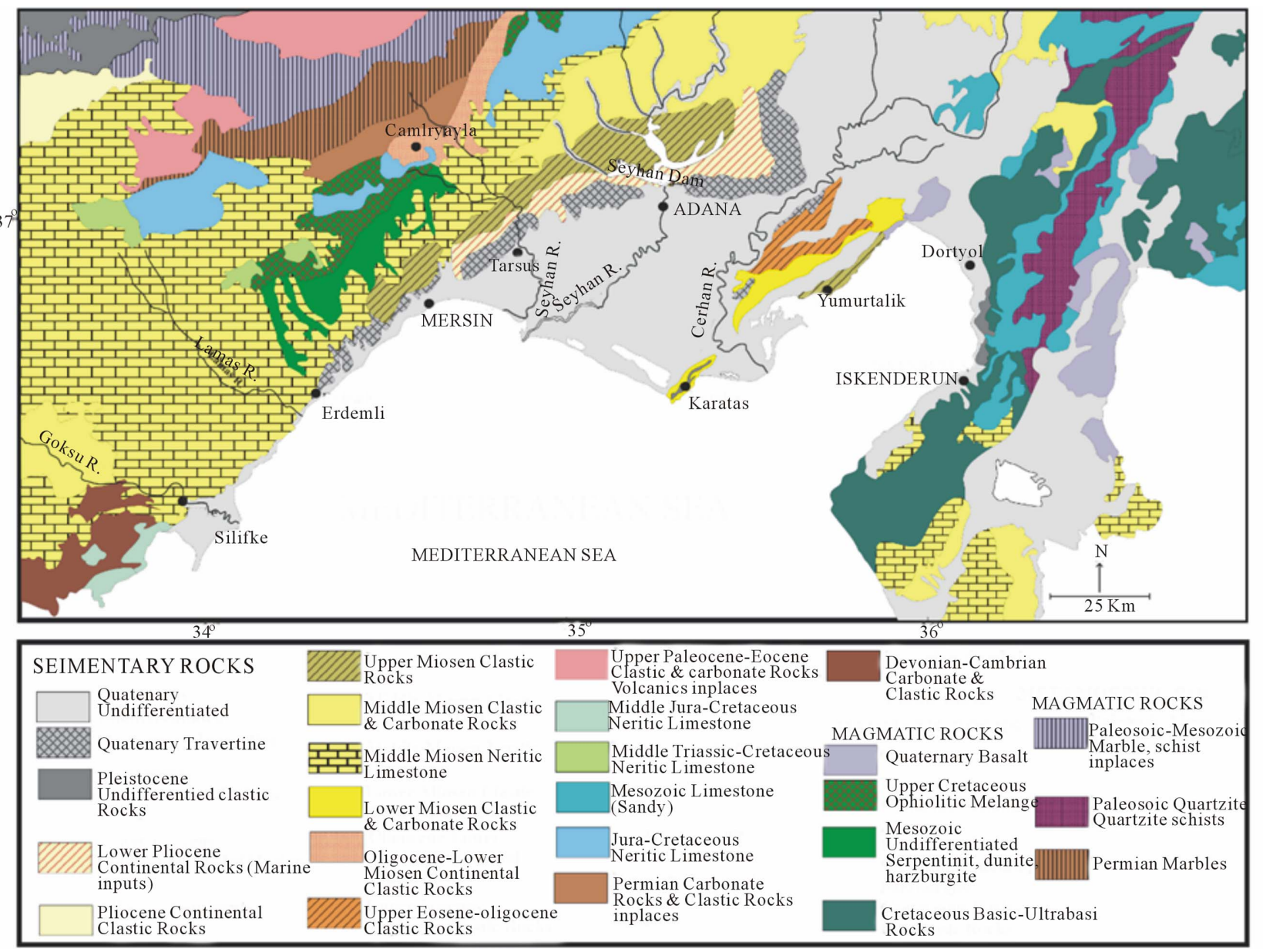

Figure 2. Geologic map of the surrounding region of study area (modified from [11]).

sediment textures ranging from sandy gravel to mud (Table 1, Figure 3). The sediments are predominantly characterized by their relatively high mud content with varying silt and clay fractions (Table 1, Figure 4). The general grain size distribution pattern of the north-eastern Mediterranean surface sediments are mainly dependent 


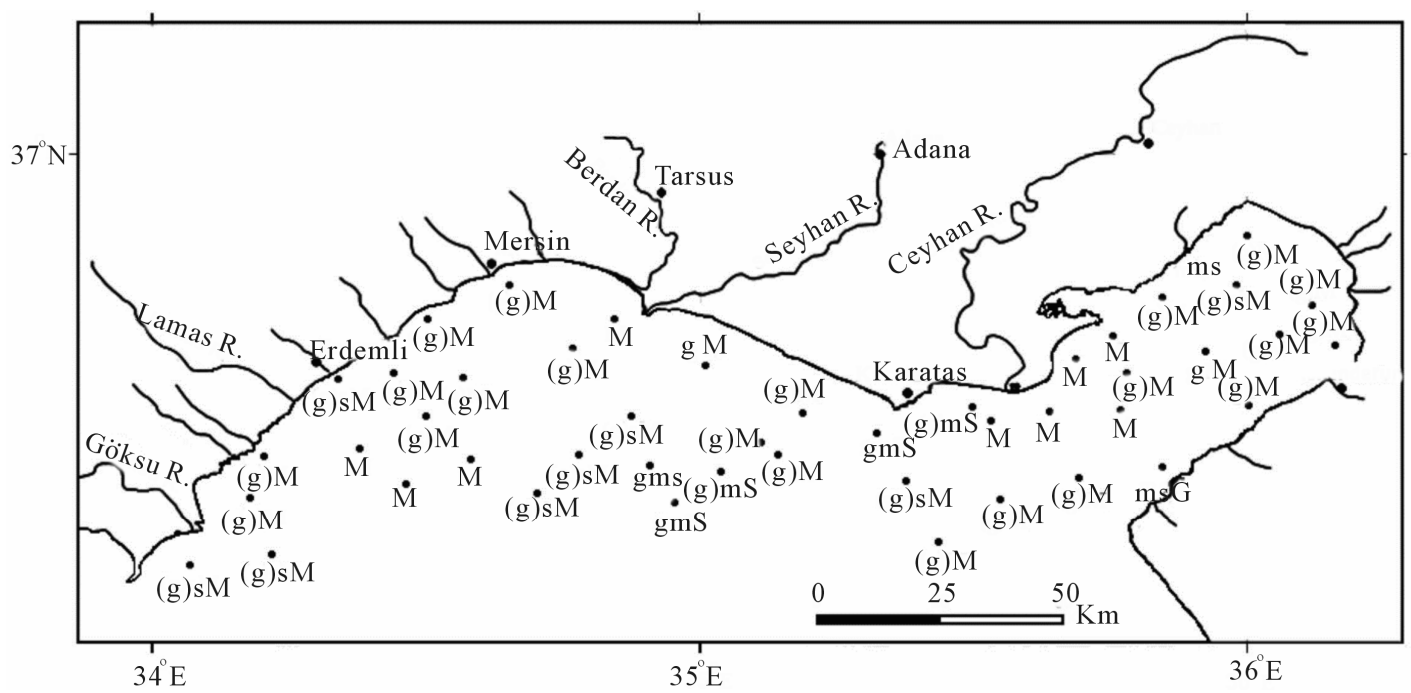

Figure 3. Textural distribution of the surface sediments in the studied area.

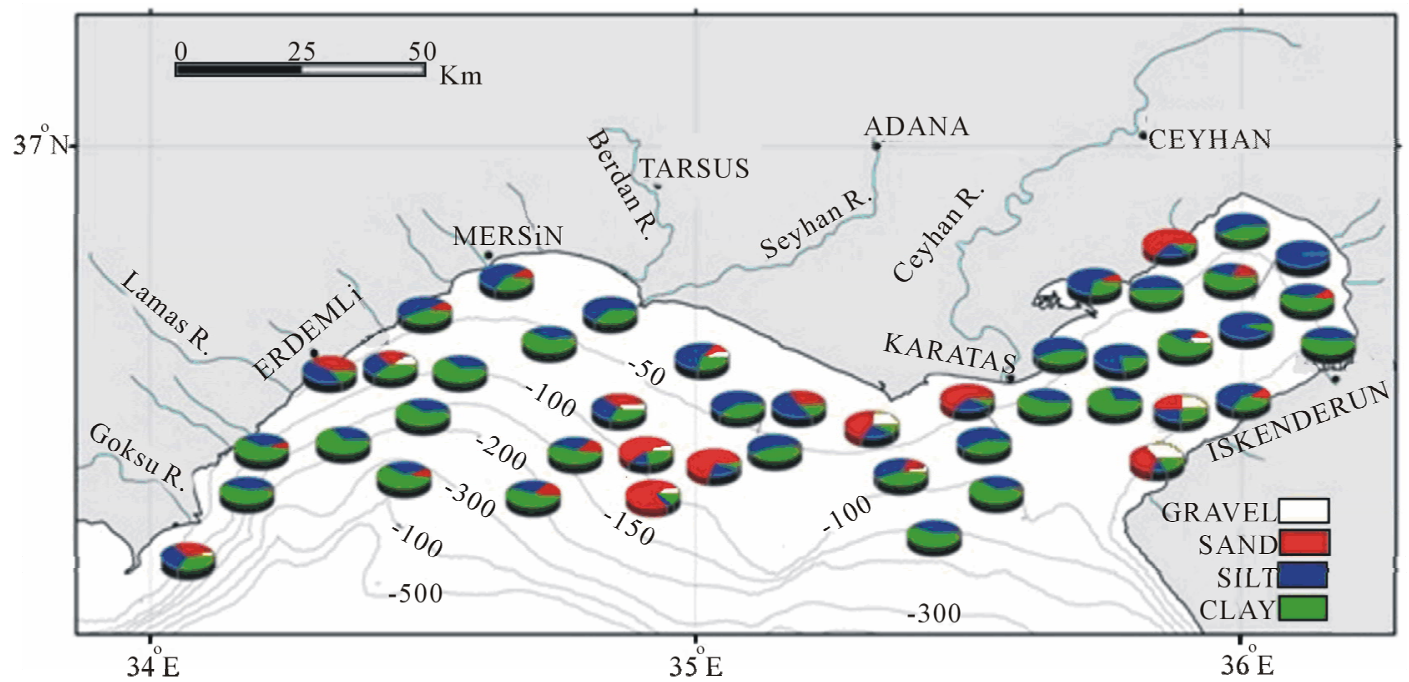

Figure 4. Pie charts showing the grain-size distribution for each station.

on the irregular bottom topography of the region and various terrigenic inputs carried by perennial rivers. Local eddies and coastal filaments occurring in the area are the other important factors controlling the grain size composition and distribution of the surface sediments.

The gravel content of the sediments generally amounted to less than $1 \%$ in the study area. High amounts of gravel were found at two stations which are mainly composed of biogenic constituents: in the southern corner of Iskenderun Bay (35\%) and in the western part of the Ceyhan River Delta (23\%) (Table 1, Figure 4). In the southern region of Mersin Bay between 50 and $100 \mathrm{~m}$ water depth the surface sediments are principally composed of sand fraction (55\% - 80\%; Table 1, Figure 4). The sediments in this area contain high amounts of biogenic remains. Furthermore, three other distinct sandy patches were found: an ephemeral deltaic area at the northern corner of Iskenderun Bay (63\%), Erdemli coastal sediments (41\%) and off Cape Karatas coastal sediments (64\%) (Table 1, Figure 4). At most stations the sand fraction of the surface sediments mainly consisted of fine sand fractions (125 - 250 microns) and the total proportion of gravel and sand fractions (coarse fractions) were less than 10\% (Figure 4, Table 1). Terrigenic material inputs from rocky coasts and biogenic shell accumulation caused an increase in coarse-grained material percentages in the coastal sediments off Karatas Cape, the Erdemli province, and the ephemeral rivers of the northeastern and south-western Iskenderun Bay. However, an unexpected coarse-grained sediment patch was located between the $50 \mathrm{~m}$ and $150 \mathrm{~m}$ contour intervals of northeastern Mersin Bay. The high amount of relict coarse material in these sediments was explained by the presence of an ancient deltaic system in that area 
Table 1. Grain size and geochemical characteristics of the sediments.

\begin{tabular}{|c|c|c|c|c|c|c|c|c|}
\hline \multirow[t]{2}{*}{ Station No } & \multirow[t]{2}{*}{ Gravel (\%) } & \multirow[t]{2}{*}{ Sand (\%) } & \multicolumn{3}{|c|}{ Mud (\%) } & \multirow[t]{2}{*}{ Texture } & \multirow[t]{2}{*}{$\mathrm{CaCO}_{3}(\%)$} & \multirow[t]{2}{*}{$\mathrm{C}_{\text {Org }}(\%)$} \\
\hline & & & Silt & Clay & Total & & & \\
\hline 1 & 4.2 & 32.7 & 29.6 & 33.5 & 63.1 & (g)sM & 50.6 & 0.32 \\
\hline 2 & 0.1 & 2.3 & 42.5 & 55.1 & 97.7 & (g)M & 24.0 & 0.29 \\
\hline 3 & 0.2 & 3.6 & 37.7 & 58.5 & 96.2 & (g)M & 33.3 & 0.41 \\
\hline 4 & 0.0 & 41.0 & 43.7 & 15.3 & 59.0 & (g)sM & 31.9 & 0.12 \\
\hline 5 & 0.0 & 1.1 & 33.8 & 65.1 & 98.9 & M & 29.4 & 0.01 \\
\hline 6 & 0.0 & 4.9 & 35.7 & 59.4 & 95.2 & M & 32.5 & 0.43 \\
\hline 7 & 10.1 & 26.6 & 25.3 & 38.0 & 63.3 & $\mathrm{gM}$ & 36.2 & 1.51 \\
\hline 8 & 0.2 & 1.2 & 38.6 & 60.0 & 98.6 & (g)M & 28.1 & 0.49 \\
\hline 9 & 1.2 & 6.4 & 49.8 & 42.6 & 92.4 & (g)M & 29.1 & 0.68 \\
\hline 10 & 0.0 & 1.1 & 36.9 & 62.0 & 98.9 & (g)M & 28.2 & 0.29 \\
\hline 11 & 0.4 & 7.1 & 58.2 & 34.3 & 92.4 & (g)M & 29.7 & 3.55 \\
\hline 12 & 2.0 & 1.2 & 38.9 & 57.9 & 96.7 & (g)M & 19.4 & 0.05 \\
\hline 13 & 0.0 & 0.9 & 61.8 & 37.3 & 99.0 & $\mathrm{M}$ & 25.3 & 2.14 \\
\hline 14 & 0.0 & 10.9 & 33.6 & 55.5 & 89.1 & (g)sM & 33.1 & 0.40 \\
\hline 15 & 0.0 & 10.2 & 35.2 & 54.6 & 89.7 & (g)sM & 33.7 & $\mathrm{n} / \mathrm{a}$ \\
\hline 16 & 3.9 & 35 & 29.2 & 31.9 & 61.1 & (g)sM & 54.5 & 0.73 \\
\hline 17 & 6.2 & 7 & 58.2 & 28.6 & 86.9 & $\mathrm{gM}$ & 29.3 & 12.03 \\
\hline 18 & 5.9 & 55.2 & 16.6 & 22.3 & 39.0 & $\mathrm{gmS}$ & 49.6 & 0.05 \\
\hline 19 & 6.6 & 80 & 4.6 & 8.8 & 13.5 & $\mathrm{gmS}$ & 75.7 & $\mathrm{n} / \mathrm{a}$ \\
\hline 20 & 2.2 & 68.2 & 23.8 & 5.8 & 29.5 & (g)mS & 40.9 & 2.99 \\
\hline 21 & 0.1 & 1.7 & 58.6 & 39.6 & 98.2 & (g)M & 29.7 & 1.49 \\
\hline 22 & 0.2 & 2.5 & 53.1 & 44.2 & 97.4 & (g)M & 26.5 & 6.56 \\
\hline 23 & 1.5 & 32 & 52.2 & 14.3 & 66.5 & (g)sM & 34.0 & 1.06 \\
\hline 24 & 22.8 & 43.8 & 25.4 & 8.0 & 33.3 & $\mathrm{gmS}$ & 51.0 & $\mathrm{n} / \mathrm{a}$ \\
\hline 25 & 3.3 & 15.2 & 37.3 & 44.2 & 81.5 & (g)sM & 34.6 & 0.43 \\
\hline 26 & 0.0 & 1.8 & 41.6 & 56.6 & 98.2 & (g)M & 28.0 & 0.08 \\
\hline 27 & 0.5 & 2.6 & 37.4 & 59.5 & 97.0 & (g)M & 29.5 & 0.58 \\
\hline 28 & 0.0 & 0.7 & 57.9 & 41.4 & 99.3 & M & 27.7 & 0.23 \\
\hline 29 & 0.1 & 63.7 & 28.8 & 7.4 & 36.3 & (g)mS & 23.0 & 10.28 \\
\hline 30 & 0.0 & 0 & 42.9 & 57.1 & 99.9 & M & 23.1 & 3.48 \\
\hline 31 & 0.0 & 0.7 & 56.2 & 43.1 & 99.2 & $\mathrm{M}$ & 27.7 & 0.24 \\
\hline 32 & 0.0 & 0.4 & 77.8 & 21.8 & 99.6 & (g)M & 21.7 & 0.98 \\
\hline 33 & 0.0 & 0.5 & 29.9 & 69.6 & 99.4 & $\mathrm{M}$ & 23.6 & 0.03 \\
\hline 34 & 34.6 & 35.9 & 12.5 & 17.0 & 29.6 & $\mathrm{msG}$ & 73.0 & 0.14 \\
\hline 35 & 0.0 & 5.5 & 66.3 & 28.2 & 94.5 & M & 26.9 & 0.86 \\
\hline 36 & 0.1 & 0.7 & 50.0 & 49.2 & 99.2 & (g)M & 27.0 & 0.72 \\
\hline 37 & 6.3 & 5.2 & 28.8 & 59.7 & 88.5 & $\mathrm{gM}$ & 29.0 & 0.65 \\
\hline 38 & 0.1 & 6.1 & 59.9 & 33.9 & 93.7 & (g)M & 29.3 & 0.36 \\
\hline
\end{tabular}


Continued

\begin{tabular}{cccccccccc}
\hline 39 & 0.0 & 62.9 & 27.4 & 9.7 & 37.1 & $\mathrm{mS}$ & 28.1 & 0.86 \\
40 & 1.9 & 15.2 & 28.0 & 54.9 & 82.8 & $(\mathrm{~g}) \mathrm{sM}$ & 31.7 & 1.13 \\
41 & 0.1 & 1.1 & 98.0 & 0.8 & 98.9 & $(\mathrm{~g}) \mathrm{M}$ & 22.7 & 0.66 \\
42 & 0.1 & 1.6 & 94.0 & 4.3 & 98.4 & $(\mathrm{~g}) \mathrm{M}$ & 22.1 & 0.93 \\
43 & 0.1 & 1.1 & 46.1 & 52.7 & 98.8 & $(\mathrm{~g}) \mathrm{M}$ & 25.2 & 0.69 \\
44 & 0.3 & 6.1 & 41.6 & 52.0 & 93.6 & $(\mathrm{~g}) \mathrm{M}$ & 29.2 & 0.29 \\
45 & 0.2 & 1.2 & 55.3 & 43.3 & 98.5 & $(\mathrm{~g}) \mathrm{M}$ & 23.4 & \\
46 & 3.8 & 32.8 & 29.8 & 33.6 & 63.4 & $(\mathrm{~g}) \mathrm{sM}$ & 48.3 & 0.24 \\
47 & 0.0 & 2.1 & 39.2 & 58.7 & 97.9 & $\mathrm{M}$ & 31.8 & 0.4 \\
48 & 0.0 & 2.1 & 39.6 & 58.3 & 97.9 & $(\mathrm{~g}) \mathrm{M}$ & 28.6 & 0.50 \\
\hline
\end{tabular}

Sediment texture was determined according to the triangular diagram [9] showing the distributions of relative proportions of gravel, sand and mud fractions.

when the global sea level was about 125 m below today's sea level at the last glacial maximum [12]. Silt content generally ranges between $20 \%$ and $40 \%$. However, high silt content $(50 \%-62 \%)$ was present between $0-50 \mathrm{~m}$ bathymetric contours along the northeastern coasts of Mersin Bay (Table 1, Figure 4). The dams on the Seyhan and Berdan Rivers act as a trap for coarse-grained sediments.

In particular, coarse-grained Seyhan River sediments are trapped at the end of the water dam and the finer sediments which escape from dams reach and accumulate at the delta systems of these rivers. The enriched silt content of the sediments found in the north-eastern side of Karatas Cape may be the result of movement of the suspended sediments with the swiping effect of the cyclonic coastal filaments of the current system prevailing in this region $[13,14]$. Towards the western-south-western region of the bay, silt content decreases and the clay content increases. The highest silt percentages were observed in south-eastern Iskenderun Bay (94\% - 98\%). There is an apparent decrease in silt content towards the south-eastern corner of the gulf which is represented by coarse-grained sediments. Clay content of the studied sediments was generally low at near-shore areas and high at offshore sites (Figure 4) with an exception being the biogenic sandy patch at the southeastern corner of Mer$\sin$.

The accumulation of clay fractions in surface sediments is generally controlled by the bottom topography and related hydrodynamic conditions. Clay fraction constitutes less than $35 \%$ in the shelf sediments and as expected from the low sinking rate of clay, these values gradually increase from shelf to off-shore. High sediment discharge in coastal areas together with the presence of biogenic shells lead to the lower percentages of clay fraction observed in the coastal sediments. The clay enrichment on the sloping face of the offshore Ceyhan Delta reflects a typical delta-front, pro-delta and offshore deposition. The sediments contain a high amount of mud fraction $(>90 \%)$ along the Iskenderun Gulf. The high presence of biogenic material and fluvial input from rocky coasts cause dilution and decrease the mud percentages of the sediments at two patches. Similar to Mersin Bay sediments, the grain size distribution pattern of the Iskenderun Bay sediments is affected by the presence of several rivers draining into the gulf and precisely coincides with the complex circulation system suggested by [13]. No significant relationship between water depth and the coarse-grained fraction of the sediments was seen (Figure 5). However, mud content displayed a close relationship between the water depths of the sediment sampling stations (Figure 5).

\subsection{Carbonate Distribution}

The total calcium carbonate $\left(\mathrm{CaCO}_{3}\right)$ content in the region varies between $19 \%-75 \%$ with an average of $34 \%$ by dry weight (Table 1). The major component of the sediments, especially muddy sediments, was $\mathrm{CaCO}_{3}$ $(20 \%-30 \%)$. The highest carbonate contents were measured at two distinct patches located in the southern corner of Iskenderun Bay and in the south-eastern region of Mersin Bay.

$\mathrm{CaCO}_{3}$ contents show a close relationship with the grain size fractions (Table 2; Figure 6). A significant and positive correlation was found between $\mathrm{CaCO}_{3}$ gravel $(\mathrm{r}=0.71)$ and $\mathrm{CaCO}_{3}$-sand $(\mathrm{r}=0.66)$. However, there was a negative (inverse) correlation between carbonate contents and the fine-grained sediment (mud) fractions ( $r=-0.75$, Table 2$)$.

$\mathrm{CaCO}_{3}$ concentrations in Iskenderun Bay show an increase in the south-eastern entrance of the gulf. Microscopic studies performed on gravel and sand fractions of Iskenderun Bay sediments showed the high carbonate content to be related to the presence of the calcareous remains of organisms such as pelecypods, gastropods, 

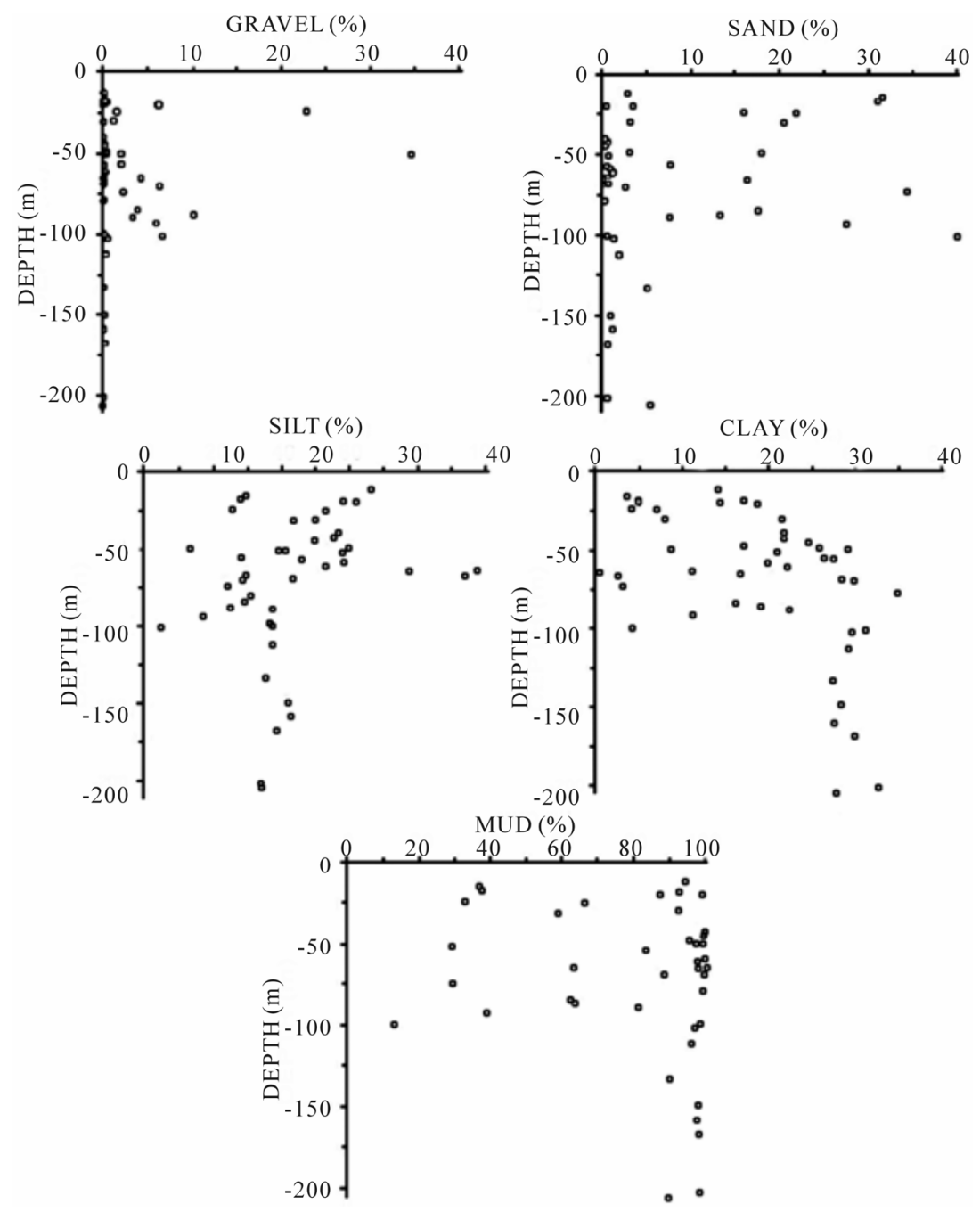

Figure 5. Plots of the grain size fractions versus water depths of sampling stations.

Table 2. Correlation (r values) between measured parameters.

\begin{tabular}{|c|c|c|c|c|c|c|c|}
\hline & Gravel & Sand & Silt & Clay & Mud & $\mathrm{CaCO}_{3}$ & $\mathrm{C}_{\text {org }}$ \\
\hline Gravel & 1.00 & & & & & & \\
\hline Sand & 0.37 & 1.00 & & & & & \\
\hline Silt & -0.43 & -0.59 & 1.00 & & & & \\
\hline Clay & -0.32 & -0.67 & -0.16 & 1.00 & & & \\
\hline Mud & -0.57 & -0.97 & 0.63 & 0.67 & 1.00 & & \\
\hline $\mathrm{CaCO}_{3}$ & 0.71 & 0.66 & -0.62 & -0.36 & -0.75 & 1.00 & \\
\hline $\mathrm{C}_{\text {org }}$ & -0.01 & 0.20 & 0.08 & -0.28 & -0.17 & -0.16 & 1.00 \\
\hline
\end{tabular}

foraminifera and bryozoa. These results agree with the findings of [7]. $\mathrm{CaCO}_{3}$ concentrations obtained for Mersin Bay were generally similar to those found in Iskenderun Bay. However, these values are slightly higher than those found in the fine-grained Mediterranean sediments (average of 20\%; [15]). The general $\mathrm{CaCO}_{3}$ dis- tribution pattern of the surface sediments in Mersin Bay shows a close relationship with the swiping pattern of wind-generated coastal filaments suggested by [16]. Low carbonate contents obtained in the Mersin Bay sediments are associated with the transport effect of these filaments on the siliciclastic materials carried by perennial and 
ephemeral rivers. The existence of high amounts of biogenic material in the coarse-grained sediment patches of the studied area increase the carbonate concentrations in these sediments.

\subsection{Organic Carbon Contents}

The organic carbon contents of the surface sediments in the study area vary regionally from $0.01 \%$ to $12 \%$ (average: $1.4 \%$ by dry weight, Table 1 ), depending on the complex interaction of biogenic, terrigenic, hydrodynamic and anthropogenic factors. The highest organic carbon concentrations $(3.55 \%-12.03 \%)$ were measured in the sediments from the eastern coasts of Mersin Bay, extending from Mersin City to the Ceyhan River Delta. In particular, sediments in the eastern section of the Seyhan River (12.03\%) and the deltaic sediments accumulated in the west of the Ceyhan River (10.28\%) contain high organic carbon, probably due to increased input from the adjacent land as well as in situ production. Clearly, anthropogenic activities in the region should be considered as additional sources for organic matter.

Contaminated waters carried by the Ceyhan, Seyhan and Berdan rivers which receive industrial waste and agricultural runoff drain into this region. A busy international harbour located in Mersin Bay and sewage outfalls in this area also prove significant sources for local enrichment of the organic carbon. Regional comparisons of our results with previous studies indicated that, the amount of organic carbon measured in this study is similar to that reported by other researchers in the eastern Mediterranean Sea [17-21].

As seen from Table 2 and Figure 7, there is no significant relationship between the organic carbon and grain
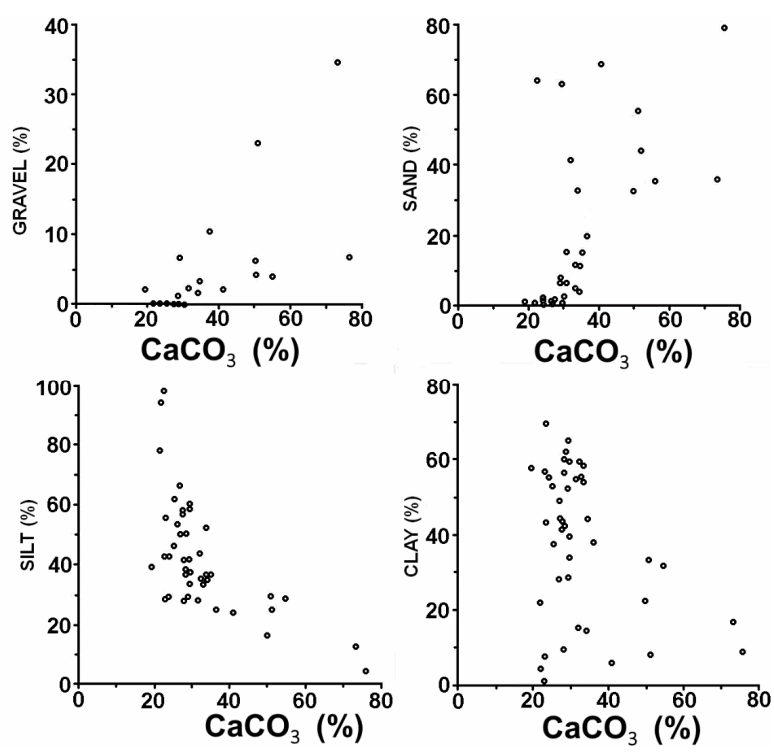

Figure 6. $\mathrm{CaCO}_{3}$ percentages in the various grain size fractions.
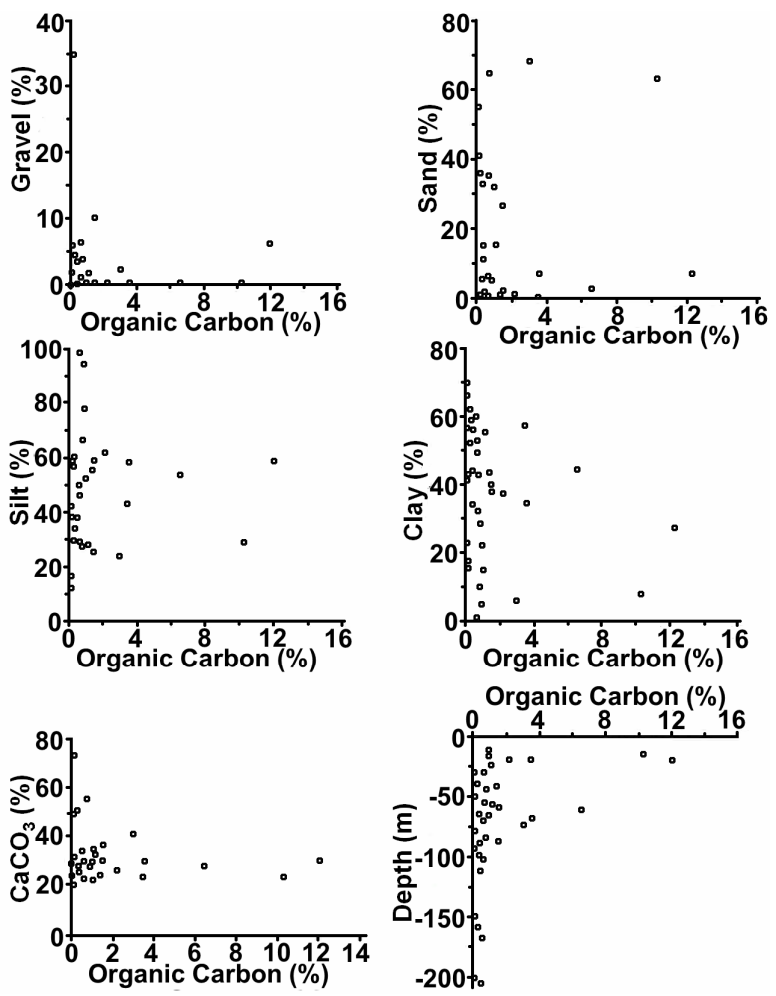

Figure 7. Organic carbon percentages versus grain size fractions, $\mathrm{CaCO}_{3}$ and depth.

size fractions ( $\mathrm{r}$ values for gravel: -0.01 ; sand: 0.2 ; silt: 0.08 and clay: -0.28$)$. Furthermore, no relationship was found between organic carbon contents and $\mathrm{CaCO}_{3}$ contents of the sediments (r: -0.16 , Table 2, Figure 7). However, water depth versus organic carbon values demonstrates a close relationship within the study area (Figure 7).

\section{Conclusions}

The recent sediments of the northeastern Mediterranean are composed of various sediment textures ranging from mud to gravelly mud. The general grain size distribution pattern of the surface sediments is determined mainly by the irregular bottom topography of the region and various terrigenic inputs carried by perennial rivers. The complex wave and current system including local eddies and coastal filaments are other important factors controlling the grain size composition of the sediments here.

The surface sediments are predominantly characterized by their relatively high mud contents with varying silt and clay fractions. The total proportion of coarse-grained fractions accounts for less than $10 \%$ in most sediment.

Generally, $\mathrm{CaCO}_{3}$ content is less than $40 \%$ and shows significant correlation with the grain size fractions. The swiping effect of the wind-generated coastal filaments plays an important role in the general $\mathrm{CaCO}_{3}$ distribution pattern of the Mersin Bay sediments. Low carbonate contents obtained in the Mersin Bay sediments are asso- 
ciated with the transport effect of the prevailing current regime on the siliciclastic materials carried by perennial and ephemeral rivers. High amounts of biogenic material accumulated in the coarse-grained sediment patches of the studied area cause high carbonate concentrations in these sediments.

Total organic carbon contents of the northeastern Mediterranean sediments mostly indicate normal marine production and hydrographically-related deposition. However, the coastal sediments of the eastern Mersin Bay, from Mersin City to the west of Ceyhan River Delta, contain relatively high organic carbon. No significant correlation exists between the grain size fractions, organic carbon and carbonate contents of the sediments. However, the variations in the organic carbon concentrations illustrate a close relationship with depth of the sampling stations.

\section{Acknowledgements}

This work is partly supported by UNEP and the Turkish Scientific and Technical Research Council (TUBITAK). The authors are very grateful to Alison Kideys who helped considerably in improving the English of this manuscript.

\section{REFERENCES}

[1] V. Ediger, "Recent Sedimentology and Holocene Evolution of the Western Shelf of the Mersin Bay (NE-Mediterranean Sea)," Ph.D. Dissertation, Middle East Technical University, Institute of Marine Sciences, Mersin, 1991.

[2] M. N. Bodur and M. Ergin, "Holocene Sedimentation Patterns and Bed Forms in the Wav-Current-Dominated near Shore Waters of Eastern Mersin Bay (Eastern Mediterranean)," Marine Geology, Vol. 108, No. 1, 1992, pp. 73-93. http://dx.doi.org/10.1016/0025-3227(92)90214-3

[3] M. Okyar and V. Ediger, "Sea-Floor Sediments and Bed Forms around Turkey Revealed by Side-Scan Sonar Imagery," Oceanologica Acta, Vol. 20, No. 5, 1997, pp. 673685.

[4] M. N. Bodur and M. Ergin, "Heavy Metal Associations in Recent Inshore Sediments from the Mersin Bay, Turkey," Bolletino Di Oceanologia Teorica Ed Applicata, Vol. 6, 1988, pp. 15-34.

[5] S. Sanın, G. Tuncel, A. F. Gaines and T. I. Balkas, "Concentrations and Distribution of Some Major and Minor Elements in the Sediments of the river Göksu and Taşucu Delta, Turkey," Marine Pollution Bulletin, Vol. 24, No. 3, 1992, pp. 167-169. http://dx.doi.org/10.1016/0025-326X(92)90246-3

[6] S. Kapur, S. L. Gokcen, C. Saydam, M. Senol, S. Senol and C. Karaman, "The Clay Mineralogy and Geochemistry of the Recent Surface Sediments of Iskenderun Bay as Indicators of Terrestrial Provenance," Zeitschrift für Geomorphologie, Vol. 73, 1989, pp. 167-180.

[7] B. Kazan, "Geochemistry of Surface Sediments in the
Gulf of Iskenderun, Eastern Mediterranean," M.Sc. Dissertation, Middle East Technical University, Institute of Marine Sciences, Mersin, 1994.

[8] M. Ergin, B. Kazan, F. Y. Eryılmaz, M. Eryılmaz and M. Okyar, "Hydrographic, Deltaic and Benthogenic Controls of Sediment Dispersal in the Gulf of Iskenderun, SE Turkey (E. Mediterranean)," Estuarine, Coastal and Shelf Science, Vol. 46, No. 4, 1998, pp. 493-502. http://dx.doi.org/10.1006/ecss.1996.0231

[9] R. L. Folk, "Petrology of Sedimentary Rocks," Hemphill Publishing Company, Austin, 1974.

[10] G. Muller, "Methods in Sedimentary Petrology," Schweizerbart, Stuttgart, 1967.

[11] MTA, “Geological Map of Turkey,” 2002. www.mta.gov.tr

[12] G. P. Weedon, "The Pleistocene - Recent Geology of Part of the Misis-Kyrenia Ridge South of Turkey," B.Sc. Dissertation in Geology, Imperial College Royal School of Mines, 1983.

[13] O. Iyiduvar, "Hydrographic Characteristics of Iskenderun Bay," M.Sc. Dissertation, Middle East Technical University, Institute of Marine Sciences, Mersin, 1986.

[14] M. B. Collins and F. T. Banner, "Secchi Disc Depths; Suspensions and Circulation," North-Eastern Mediterranean Sea Marine Geology, Vol. 31, No. 1-2, 1979, pp. 39-46.

[15] E. M. Emelyanov and K. M. Shimkus, "Geochemistry and Sedimentology of the Mediterranean Sea," Sedimentology and Petroleum Geology, Vol. 1, 1986, in press. http://dx.doi.org/10.1007/978-94-009-4490-9

[16] G. Evans, G. F. Lane-Serff, M. B. Collins, V. Ediger and C. B. Pattiaratchi, "Frontal Instabilities and Suspended Sediment Dispersal over the Shelf of the Cilician Basin, Southern Turkey," Marine Geology, Vol. 128, No. 3-4, 1995, pp. 127-136. http://dx.doi.org/10.1016/0025-3227(95)00093-E

[17] E. M. Emelyanov, "Principal Types of Recent Bottom Sediments in the Mediterranean Sea-Their Mineralogy and Geochemistry," In: D. J. Stanley, Ed., The Mediterranean Sea-A Natural Sedimentation Laboratory, Dowden, Hutchinson and Ross, Stroudsburg, 1972, pp. 355-386.

[18] F. V. Taliadouri and J. Satsmadjis, "Concentration of Some Metals in Aegean Sediments," Revue Internationale d'Oceanographie Medicale, Vol. 66-67, 1982, pp. 71-76.

[19] M. Ergin, S. N. Alavi, M. N. Bodur, V. Ediger and M. Okyar, "A Review of the Geology and Geochemistry of the Northeastern Mediterranean Basins," Middle East Technical University Press, Ankara, 1988.

[20] M. Ergin, V. Ediger, M. N. Bodur and M. Okyar, "A Preliminary Study of the Principal Recent Sediment Types along the Eastern Margin of the Aegean Sea," 32nd Congress and Plenary Assembly of CIESM, 15-20 October 1990, Perpignan, p. 103.

[21] M. Ergin, M. N. Bodur, V. Ediger, S. Yemenicioglu, M. Okyar and N. Kubilay, "Sources and Dispersal of Heavy Metals in Surface Sediments along the Eastern Aegean Shelf," Bollettino di Oceanologia Teorica ed Applicata, Vol. 11, No. 1, 1993, pp. 27-44. 